\title{
ANÁlISES FísICO-QUíMICAS DE SISTEMAS \\ MARGINAIS MARINHOS
}

\section{Carlos Augusto Ramos e Silva}

As regiōes costeiras sempre foram alvo do desenvolvimento de comunidades humanas face às riquezas naturais presentes e à beleza paisagística apresentada pela região. A ocupação destas áreas, muitas vezes não planejada, acarreta em alterações significativas na qualidade ambiental das mesmas. Sendo assim as regiōes marginais marinhais vêm sendo objeto de estudos das mais diversas áreas, estudos estes que muitas vezes necessitam de um grande número de análises químicas das águas destas regiōes.

Essas análises incluem desde "simples" medições de $\mathrm{pH}$ até medições mais complexas, envolvendo, por exemplo, o sistema carbonato (alcalinidade total e alcalinidade carbonática). É freqüente a utilização de técnicas analíticas apropriadas à água doce em água do mar ou salobra, ou utilização de precisão inadequada, por falta de conhecimento básico. Algumas medições, como o $\mathrm{pH}$, requerem valores de $\pm 0,1$ unidades de $\mathrm{pH}$ quando o objetivo é o monitoramento da qualidade da água e de $\pm 0,01$ unidades de $\mathrm{pH}$ quando o objetivo é a caracterização do sistema carbonato ou estudar a produção primária. Essas precisôes só podem ser conseguidas através da escolha e do uso adequado do método analítico para água do mar (ou salobra).É preciso ressaltar a incontestável diferença entre as propriedades da água doce e da água do mar e conseqüentemente nas técnicas a serem utilizadas.

O livro em questão descreve os métodos analíticos (conceituados a nível nacional e internacional) apropriados às águas marinhas de forma clara e didática, permitindo assim que haja uma padronização e nivelamento metodológico entre os profissionais que trabalham nesta área.

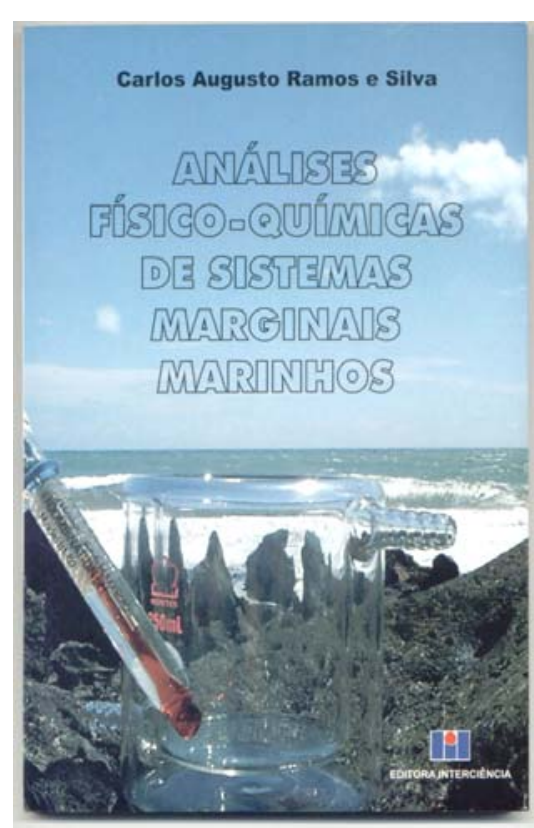

O capítulo 1 - Controle de Qualidade na Química Analítica - aborda os fatores que afetam a qualidade, técnicas analíticas e unidades de concentração.

O capítulo 2 - Introdução à FísicoQuímica de Águas Naturais - traz informações básicas sobre a físico-química marinha, focando os conceitos fundamentais da termodinâmica.

No capítulo 3 são elucidados o uso e a limitação da termodinâmica em sistemas marinhos, focando a saturação do oceano com carbonato de cálcio.

O capítulo 4 é constituído de um detalhado manual voltado para análises físico-químicas marinhas: oxigênio dissolvido, salinidade (escala prática de salinidade), clorinidade, potencial hidrogeniônico $(\mathrm{pH})$, alcalinidade, fósforo, nitrito, nitrato, amô- nia $\left(\mathrm{NH}_{3}+\mathrm{NH}_{4}^{+}\right)$, ferro (II), silicato e clorofila. Cada procedimento analítico é contemplado com uma introdução teórica (considerações gerais) bastante didática e esclarecedora. No caso do $\mathrm{pH}$, por exemplo, são descritas as escalas de $\mathrm{pH}$ (NBS, total, livre e da água do mar) e as unidades de concentração.

O capítulo 5 - Termos Utilizados em Química Analítica - trata das definiçôes desses termos, como atividade, constante estequiométrica $\left(\mathrm{k}^{*}\right)$, constante termodinâmica $(\mathrm{k})$, força iônica, propriedades coligativas, entre outros.

Para que se obtenha êxito no conhecimento e emprego de métodos analíticos específicos para ambientes aquáticos marinhos é de fundamental importância que os leitores particularmente interessados estudem e estimulem a consulta sistemática deste livro tornando o mesmo uma parte do laboratório.

Comentários feitos por Ada Cristina Scudelari Professora da Universidade Federal do Rio Grande do Norte - UFRN

\section{Goordemador da columa Livgosa Prof. Gigero Onofae de Amdrade Neto}

A sessão "Livros Técnicos", que a cada edição traz resumos comentados sobre livros de interesse na área, tem como principal objetivo permitir que o leitor, de forma rápida, se atualize e conheça o que há disponível no mercado editorial. As contribuiçóes deverão ser encaminhadas para: esa@abes-dn.org.br 